\title{
Climate Hypocrisies: a Comparative Study of News Discourse
}

DOI:

10.1080/17524032.2018.1474784

\section{Document Version}

Accepted author manuscript

Link to publication record in Manchester Research Explorer

\section{Citation for published version (APA):}

Gunster, S., Fleet, D., Paterson, M., \& Saurette, P. (2018). Climate Hypocrisies: a Comparative Study of News Discourse. Environmental Communication. https://doi.org/10.1080/17524032.2018.1474784

\section{Published in:}

Environmental Communication

\section{Citing this paper}

Please note that where the full-text provided on Manchester Research Explorer is the Author Accepted Manuscript or Proof version this may differ from the final Published version. If citing, it is advised that you check and use the publisher's definitive version.

\section{General rights}

Copyright and moral rights for the publications made accessible in the Research Explorer are retained by the authors and/or other copyright owners and it is a condition of accessing publications that users recognise and abide by the legal requirements associated with these rights.

\section{Takedown policy}

If you believe that this document breaches copyright please refer to the University of Manchester's Takedown Procedures [http://man.ac.uk/04Y6Bo] or contact uml.scholarlycommunications@manchester.ac.uk providing relevant details, so we can investigate your claim.

\section{OPEN ACCESS}




\title{
Climate Hypocrisies: A Comparative Study of News Discourse
}

\author{
Shane Gunster \\ School of Communication \\ Simon Fraser University \\ Burnaby, BC Canada \\ sgunster@sfu.ca \\ Darren Fleet \\ School of Communication \\ Simon Fraser University \\ Burnaby, BC Canada \\ dfleet@sfu.ca \\ Matthew Paterson \\ Politics, School of Social Sciences \\ The University of Manchester \\ Manchester, United Kingdom \\ matthew.paterson@manchester.uk \\ Paul Saurette \\ School of Political Studies \\ University of Ottawa \\ Ottawa, ON Canada \\ Paul.Saurette@uottawa.ca
}

\begin{abstract}
This paper conducts a comparative study of how the idea of hypocrisy was invoked in media coverage of climate change in twelve newspapers from four countries (Canada, Australia, United Kingdom, United States) between 2005 and 2015. It develops the concepts, and explores the characteristics, of three distinct types of climate hypocrisy: personalized (which attacks the moral character of individuals based upon inconsistencies between their stated beliefs and behaviour); institutional-analytic (which identifies contradictions between institutional rhetoric and ongoing policies and practices); and reflexive (which develops sympathetic accounts of the


struggles individuals face in reconciling the tension between values and actions). It explores how these types are used to undermine the credibility of climate advocates as well as to argue for more aggressive climate action, and maps out key features of climate hypocrisy discourse including ideological attributes, targeted actors and behaviours, affective intensity and regional variations. It outlines a number of surprising key findings, including (i) that hypocrisy discourses are more frequently invoked by 'progressives' supporting climate change action than by 'conservatives' resisting climate change action, and (ii) that while both groups use hypocrisy discourse, they tend to use very different types of hypocrisy discourses which each likely have very different impacts on climate change discourse..

Keywords: climate change, hypocrisy, news media, climate politics, content analysis

WORDS: 7254 


\section{Introduction}

Accusations of hypocrisy have become a common feature of climate change discourse. Media interviews with environmentalists, for example, commonly feature questions that interrogate their own consumptive and behavioural patterns - 'How did you get to the studio? Do you own a car?' - with the aim of rooting out the ostensible hypocrisy of seeking emissions reductions while engaging in carbon-intensive lifestyles. Yet with a few notable exceptions (especially Attari et al. 2016, and Schneider et al. 2016), there has been no scholarship in environmental communication (or within environmental studies more broadly) that specifically attends to how this theme is deployed in public discourse around climate change. This study aims to address this gap with a comparative analysis of how hypocrisy was used in news about climate change in twelve newspapers from four countries (Canada, Australia, United States, United Kingdom) over a ten-year period (2005-2015).

Motivating this research is an interest in engaging with provocations that are difficult to neutralize or sufficiently rationalize. Often dismissed as a conservative talking point, the resonance - the affective stickiness of hypocrisy - reflects a constellation of underlying beliefs both about hypocrisy and about the nature of social change. Climate change invites discomfort. To acknowledge the full implications of the climate crisis is to encounter some level of bad feeling (Norgaard 2011). In this way, the relationship between discomfort and hypocrisy is selfevident, making action or inaction on climate change open to accusations of duplicity. Individuals irreducibly live in social contexts, where constant negotiation, compromise and judgment over their values and actions are the norm, and thus failures to live up to one's professed principles necessarily invite moral censure. 
This article attempts to map some of the discursive attributes and formulations of these social, political, and cultural intersections: Who is the accuser? Who is the target? What type of affect is cultivated? What is the intention of the discourse - to halt social change or to push it forward? What role might this discourse play in either motivating, or limiting action on climate change? Overall, what we present is a discourse far more complex and varied than commonly considered, as well as a discourse that opens up the possibility for more generative understandings of hypocrisy.

We seek thus to contribute to an emerging literature on the cultural politics of climate change (Bulkeley et. al. 2016; Crow \& Boykoff 2014; Hulme 2010). A key theme in that work is to think about responses to climate change in terms that move beyond the individualism and rationalism of economics, reducing climate change to a question of individual action and thinking of climate change politics only in terms of changing incentive structures for individuals. Rather, responses to climate change need to be understood in terms of the interplay between what Bulkeley et. al. (2016) term "devices" (individual technologies, objects, and assemblages of these objects), "desires" (affective relations to these devices and to climate change itself), and "dissent" (the political mobilisation of these affective responses). Hypocrisy discourse is illuminating precisely because it works to purify these various complexities, seeking to reduce them to a question of individual choice regarding consumption activity. However, as we show below, exploring how it works in practice demonstrates that hypocrisy discourse can also disclose precisely how these complexities can be opened up again. As such, the article contributes to thinking about the complicated politics of remaking desires associated with responses to climate change. Elsewhere (Gunster et. al. 2017), we undertake a more 4 
qualitatively-focused critical discourse analysis to explore the specific rhetorical tactics through which different types of hypocrisy discourse operate, which allows for a fuller discussion of what our analysis of hypocrisy discourse tells us about the broader dynamics of cultural politics. Here, however, our aim is broadly schematic in nature, to map quantitatively the dominant forms, principal variations and key contours of climate hypocrisy in newsprint media.

We begin by surveying how hypocrisy has been discussed in existing literature on climate change. In the second section, we set out our method for analyzing climate hypocrisy discourse. The third section details the results of our analysis. In particular, it outlines the different purposes of hypocrisy discourse in relation to climate change action, the types of items in newspapers where the discourse is used, the principal targets of attack, and the role of negative affect in the articles. It then outlines the three types of climate hypocrisy discourse we identify in our dataset, which we term personalised, institutional-analytic, and reflexive hypocrisy discourse respectively. The article concludes by drawing out the implications of the analysis for climate change communication and politics.

\section{Hypocrisy and climate change discourse}

John Urry notes that "hypocrisy is a major issue in questions of climate change mitigation leadership" (2011, p. 156). Other scholars have similarly noted various aspects of what we call 'climate hypocrisy', including: the risk of hypocrisy in celebrity advocacy (Anderson 2011; Boykoff 2008; Cooper et. al. 2012); the use of hypocrisy to attack the credibility of climate scientists and environmental activists (Gavin \& Marshall 2011; Gunster \& Saurette 2014; Knight \& Greenberg 2011; Marshall 2014; Mayer 2012); public and activist criticism of the hypocrisy of 
state actors and climate policy (Eckersley 2013; McGregor 2015; Platt \& Retallack 2009; Webb 2012); hypocrisy's effect in shifting climate discourse into a moral, emotional register (Young 2011; Dannenberg et al 2012); representations of the general public as hypocritical (Höppner 2010); and the hypocrisy of 'green' consumerism (Barr 2011; Laidley 2013). For the most part, however, these references to climate hypocrisy are cursory and often under-developed, merely gesturing towards the idea's rhetorical significance.

Two recent exceptions to this cursory treatment suggest the usefulness of more robust investigation into different variants of climate hypocrisy. Attari et. al (2016) conducted two experimental surveys which measured how disclosure of a climate researcher's carbon footprint affected their credibility as an advocate of behavioural change. Predictably, revelations about carbon-intensive behaviour (frequent flying and/or high home energy use) significantly reduced perceptions of credibility as well as the inclination of audiences to reduce their own energy consumption. The study was widely reported in environmental media such as Inside Climate News (Yoder 2016) and Grist (Song 2016); it also headlined an extended post on the popular climate denial blog Watts Up With That? (Watts 2016). In “The Hypocrite's Trap," Schneider et. al. (2016) surveyed how U.S. fossil fuel industries and their allies invoke hypocrisy to undermine the credibility and moral suasion of the divestment movement through personalized, ad hominem attacks. More importantly, they also explored the ideological use of climate hypocrisy to champion an intensely neo-liberal, individualized approach to social change in which market and consumer choices are normalized as the only legitimate avenues of (depoliticized) agency and expression. 
These two articles offer fascinating explorations into how hypocrisy is mobilized in two key areas of climate discourse. We aim in this article to build on their insights through a more systematic overview of how the discursive field(s) of climate hypocrisy are structured, the principal features of different (and often contradictory) types of hypocrisy discourse and, most importantly, how they intersect with the competing projects of building support for climate action on the one hand, and cultivating scepticism, apathy and hostility to such action on the other.

News and journalism continues to serve as one of the most influential venues for not only informing citizens about climate science, politics and policy (Boykoff 2011), but developing the narratives (McComas \& Shanahan 1999; Mayer 2012), storylines and arguments (Gunster \& Saurette 2014), frames (Nisbet 2009), ideological cultures (Carvalho 2007) and associated forms of subjectivity (Carvalho 2010), patterns of affect (Höijer 2010) and practices of (dis)engagement (Hackett et. al. 2017) through which people come to understand, talk, care and act around climate change. As such, it serves as an ideal site in which to investigate how competing discourses of climate hypocrisy have been developed.

We use discourse to refer, in Dryzek's terms, to a "shared way of apprehending the world. Embedded in language, it enables those who subscribe to it to interpret bits of information and put them together into stories and accounts. Discourses construct meanings and relationships, helping to define common sense and legitimate knowledge" (Dryzek 2005, p. 9). This enables us to speak of "climate hypocrisy" in the singular, but it is more precise (as the empirical analysis will show) to speak of different discourses deploying climate hypocrisy to refer to something more specific. This conceptualization of discourse also enables a focus on 
conflict between competing discourses, or "discourse coalitions" (Hajer 1995), as constitutive of political life.

\section{Method}

Our discursive data set was constructed by using Factiva to conduct keyword searches for "global warming" or "climate change" and "hypocrisy", "hypocrite" or "hypocritical" in order to identify the top sources of 'climate hypocrisy' discourse among English-language newspapers in Canada, Australia, the United Kingdom and the United States between January 1, 2005 and August 15, 2015. We selected the two newspapers with the most articles responding to these keyword searches in each country for inclusion in our sample: in Canada, The National Post (owned by Postmedia) and The Globe and Mail (Woodbridge Company); in Australia, The Australian (News Corp.) and The Telegraph (News Corp.); The Guardian (Guardian Media Group) and The Telegraph (Telegraph Media Group) in the United Kingdom; and The Wall Street Journal (News Corp.) and The New York Times (Ochs-Sulzberger family) in the United States. In addition, we added the newspaper in each country with the highest circulation as of 2015: in Canada, The Toronto Star (Torstar Corp.); The Herald-Sun (News Corp.) in Australia; The Sun (News Corp.) in the United Kingdom; and in the case of the United States, given that this paper - The Wall Street Journal - was already in our sample, we instead added The Washington Post (Jeff Bezos) as it had the third highest number of climate hypocrisy items among US newspapers. Our total sample, then, consists of twelve prominent daily newspapers which harbour a diversity of ideological perspectives on climate change both across and between countries, with ideology here understood simply as "a system of values, norms and political 
preferences, linked to a program of action vis-à-vis a given social and political order" (Carvalho 2007, p. 225). These perspectives range from The Guardian's aggressive championing of proclimate actions and policy to conservative papers such as The National Post, The Wall Street Journal and The Herald-Sun which are not only critical of climate policy but often marshal their editorial resources to promote scepticism about climate science (e.g. Huertas \& Adler 2012). We are confident that this comprehensive approach provides a good representation of how the language of hypocrisy has been mobilized around climate change in these four countries over the last decade.

Items were initially collected through a keyword search and then manually reviewed to exclude pieces where discussions of climate change and hypocrisy were not directly linked. This generated a final sample of 892 items across the twelve papers. The number of items per paper ranged from a high of 162 pieces in The Guardian and 129 in The National Post to less than 30 in both The Wall Street Journal and The New York Times, suggesting that the distribution of climate hypocrisy discourse is quite uneven across both papers and countries. Perhaps surprisingly, the US papers had significantly fewer items (108) than the other three countries, Australia with 274, Canada with 263 and the UK with 247. Given that the total volume of climate change coverage in the US papers during this period was broadly comparable to the other regions (based on a simple keyword search on the topic), the lower US numbers cannot simply be attributed to lower overall attention to this topic. With respect to the chronological distribution of items, there was a sharp spike of attention to climate hypocrisy in 2007 (205), smaller spikes in 2009 (123) and 2010 (99), with a fairly stable number of items in other years ranging from 45 to 80 items per year; temporal variation within regions was broadly consistent. 
The years 2007 and 2009-10 map closely with the release of Al Gore's film, An Inconvenient Truth and his award of the Nobel Peace Prize, and the $15^{\text {th }}$ Conference of the Parties to the UN Framework Convention on Climate Change, held in December 2009 in Copenhagen.

A selection of items from each source was initially reviewed to identify key features of climate hypocrisy discourse and develop a coding schematic to conduct a content analysis of the entire sample. This initial review suggested that climate hypocrisy discourse was considerably more diverse than we had expected.

Specifically, we identified three distinct variants of climate hypocrisy: a) personalized hypocrisy, which primarily involves attacking the moral character of an individual, or group of individuals, based upon an inconsistency between their stated beliefs about climate change and their personal behaviour, or lifestyle choices (this version very closely resembles the 'ad hominem' attack of classical rhetorical analysis and is the one that most people would probably imagine if asked to define an attack using the logic of hypocrisy); b) institutional-analytic hypocrisy, which primarily identifies contradictions between the commitments and claims of politicians, governments and other institutions around climate change and their ongoing policies, practices and (in)action; it does not directly target individuals for moral sanction, but delivers a more analytic critique of structures and institutions, and mostly is used to promote rather than oppose action on climate change; and, c) reflexive hypocrisy, which develops a more sympathetic, reflective and often confessional account of personal climate hypocrisy, challenging readers to move beyond simplistic moral judgements in understanding and assessing contradictions between values, statements and behaviour, and to consider the structures that make sustainable behavioural change more than simply a matter of personal choice, willpower or 10 
integrity.

In addition to coding for these three distinct forms of climate hypocrisy, we also coded for several additional characteristics of each item, as described in Table 1 [insert Table 1 here]. All items were coded by the second author, with the lead author coding $10 \%$ of the sample to assess inter-coder reliability as measured by Krippendorff's alpha (Krippendorff 2004). The full results of this test are reported in the appendix. With the exception of two variables - reflexive hypocrisy and negative affective intensity - inter-coder reliability testing of all variables achieved a Krippendorff's alpha coefficent of .8 or higher. The coefficient for reflexive hypocrisy was .792 and .77 for negative affective intensity. While some caution is appropriate in the treatment of these two variables (especially negative affective intensity), use of these variables to identify broad, directional patterns in the sample is acceptable (Krippendorff 2004: 429). The results of these two variables map consistently with our overall findings.

\section{Results}

Pro vs anti-climate hypocrisy

The most significant (and surprising) finding of our analysis is the fact that, considered across the entire sample, discussions of hypocrisy and climate change were more likely to appear in items supporting climate action (44.4\%) rather than undermining it (35.3\%). In a similar vein, criticism directed towards the hypocrisy of institutions and their representatives - governments, politicians, political parties, corporations and others - was more common, occurring in $50.2 \%$ of items, than attacks calling out individuals for hypocritical lifestyles and personal behaviour which appeared in $36.0 \%$ of items. 
The distribution of these sentiments across newspapers, however, was quite uneven with different sources developing starkly different accounts of climate hypocrisy depending, in large part, upon their broader orientation to climate change politics and policy. It is also worth noting that there was relatively little diversity within individual items: over three-quarters (79.7\%) were either clearly for or clearly against taking climate action and close to $90 \%$ targeted either individuals or institutions (but not both) as climate hypocrites.

What we found, in other words, was the presence of several competing but largely selfcontained discourses of climate hypocrisy that were mobilized in different and often contradictory ways by supporters and opponents of climate action. As Table 2 and Figure 1 [insert Table 2 and Figure 1 here] illustrate, pro- and anti-climate applications of climate hypocrisy were often highly concentrated in particular newspapers. The papers can be roughly divided between two broad ideological clusters in relation to climate change: conservative (those papers in which the number of anti-climate action items outnumber the pro-climate action items) and progressive (those papers in which the opposite is true). Seven newspapers, accounting for just over half (58.6\%) of all items, fall on the conservative/anti-climate side with five papers, with just under half of all items (41.4\%), in the progressive/pro-climate cluster. In Table 2 we hierarchically present the sources according to the ratio between anti- and pro-climate stories with the most conservative papers at the top and the most progressive on the bottom: in the top two conservative papers, for example, discussions of climate hypocrisy are five times more likely to occur in stories which criticize rather than support climate action. At the opposite end of the spectrum, climate hypocrisy appears almost exclusively in stories making the case for a more aggressive approach to emissions reduction. 
On the conservative end of the spectrum, The National Post from Canada and The HeraldSun from Australia stand out with the second and fourth highest number of items in the total sample and the strongest overall anti-climate orientation. In both cases, the key driver was a single columnist who consistently positioned climate hypocrisy as a master-narrative for not only challenging the credibility of climate advocates but affording a privileged vantage point on the ethical, philosophical, political and even psychological contradictions that allegedly plague contemporary environmentalism. Peter Foster, a business columnist for The National Post, authored 55 columns that discussed climate hypocrisy over the last decade, accounting for over $40 \%$ of the paper's items and close to $60 \%$ of its anti-climate action pieces. Equally dominant was Andrew Bolt, a political columnist for The Herald-Sun (and occasionally the Australian Telegraph). In total, he published 45 columns during the sample period, 37 in The Herald-Sun and 8 in The Telegraph, accounting for over $40 \%$ of the Herald-Sun's items and close to $70 \%$ of its anti-climate hypocrisy stories. Foster and Bolt were by far the most prolific authors in the sample, together responsible for close to twenty percent of the items in the conservative papers. The third most frequent commentator on climate hypocrisy was James Delingpole - also a conservative columnist writing for the UK Telegraph - with 16 pieces. As Figure 2 [insert Figure 2 here] shows, columnists were especially prominent in the conservative papers and led the way in articulating climate hypocrisy with an anti-climate perspective. News items were a comparatively small proportion of the conservative sample $(22.6 \%)$ and there were somewhat more pro-climate than anti-climate pieces (46 to 31), with a significant number of items (33) including both positions. Conversely, columns dominated the conservative papers, accounting for almost half of all items, and they overwhelmingly argued against the need to mitigate climate 
change. Editorials, op-eds and letters-to-the-editor similarly prioritized anti-climate arguments but they occupied a much smaller part of the climate hypocrisy news footprint. It is worth noting that five of the seven papers in the conservative cluster are part of News Corp. while not a single paper on the progressive side of the ledger is owned by the conglomerate (see News Corp n.d.).

The five progressive papers display a very different pattern (see Figure 3 [insert Figure 3 here]), where references to climate hypocrisy appear almost entirely in the context of items which argue for more aggressive climate action: over three-quarters of items unambiguously supported stronger action with less than $10 \%$ advancing an anti-climate perspective. The Guardian was especially striking in this regard. The fact that it had the most items in the sample can, in part, be attributed to its overall emphasis on climate coverage: during the sample period The Guardian published almost twice as many items about climate change as the next highest source (as determined by a simple Factiva keyword search). Nevertheless, the higher overall prevalence of climate hypocrisy discourse in progressive papers also suggests that its use is more than simply a rhetorical strategy to undermine the credibility of climate advocates. Unlike the conservative papers, discussion of climate hypocrisy was much more evenly distributed across different types of news discourse with, for example, a roughly equal split between news and feature items (165) and the more opinion-driven discourse of columns, editorials, op-eds and letters-to-the-editor (194). Columnists, in particular, played a much smaller role in the progressive papers, authoring less than half the number of items as their counterparts in the conservative papers. There were, for example, no individual champions - like Foster and Bolt developing a consistent pro-climate narrative around climate hypocrisy. Instead, authorship was widely dispersed among a large number of journalists, columnists and others. Indeed, it is telling 14 
that two of the top three authors in the progressive papers were actually conservative columnists - Ed Rogers in The Washington Post and Margaret Wente in The Globe and Mail - who invoked hypocrisy to attack, rather than support pro-climate action. Jeffrey Simpson, a Globe and Mail political columnist, was the only pro-climate author among the top five authors in the overall sample with 11 columns.

\section{Item type}

Overall, columns were both the single largest source of material in the sample, accounting for almost $40 \%$ of items. As illustrated in Figure 4 [insert Figure 4 here], anti-climate columns outnumbered those favouring stronger action by more than a two to one margin. Conversely, the ratio of pro- to anti-climate items was 5.3 in news and features, 1.2 in editorials, 2 in guest opeds and 1.3 in letters. These results suggest that the ideological division between conservative and progressive papers could be similarly applied to item types, with columns serving as the primary venue - across all papers - through which conservative arguments about climate hypocrisy were developed, circulated and reproduced.

There are 23 columnists in the sample who published at least three pieces on climate hypocrisy: together, they accounted for 231 items, or over one-quarter of the total sample. Fourteen were conservative (with more anti- than pro-climate columns), six were progressive and three were balanced (with a roughly even distribution). Most conservative columnists were primarily based in conservative papers (11 of 14); but, notably, there were as many prominent conservative columnists (3) in the progressive papers as there were prominent progressive columnists. The distribution of these top 23 columnists across regions was also highly uneven 
with nine writing in Australian papers, eight in Canada, four in the United Kingdom and only two in the United States: indeed, the low number of columns in US newspapers - which amounted to less than one-quarter of the columns in Canada, for example - is a key reason why climate hypocrisy discourse received so much less attention in the U.S. sample than in other regions.

Unsurprisingly perhaps, scepticism about climate science played a significant role in the conservative papers, appearing in close to one-third of all items, but was virtually absent in the progressive papers with less than $5 \%$ of items adopting this perspective. More interesting is the fact that, as Figure 5 [insert Figure 5 here] illustrates, climate denial was almost entirely confined to opinion pieces and, in particular, to the columns. Even in the conservative papers, less than $10 \%$ of news items about hypocrisy referred to climate denial as compared to almost half of the columns, and one-quarter of the editorials and op-eds. Three individual columnists - Foster, Bolt and Delingpole - account for almost half of all items in the sample that challenged climate science. This finding reinforces earlier research highlighting the role of conservative columnists in spreading climate denial (Elsasser \& Dunlap 2013) and, by offering data beyond the American context of their work, offers further evidence that conservative columnists are central amplifiers of this line of argumentation in the mainstream media.

Given the focus of our research and its discourse analysis methodology, however, our research does not offer any particular insight on the question of the degree to which any of these columnists are 'directly' connected to the funding mechanisms of the "denial machine" as outlined by various scholars (e.g. Oreskes \& Conway 2011). On the face of it, Bolt and Foster do not appear to be directly connected. Delingpole may be more directly connected as he now 16 
works as a climate columnist for Breitbart. But we cannot make any firm conclusions on that. What we can say is that all three clearly deploy forms of rhetoric that help create the affective resonances that prime the audience of the conservative "echo chamber" (Elsasser \& Dunlap 2013; Jamieson \& Cappella 2008) to accept climate denialism discourse as well.

\section{Targeted actors and behaviours}

As noted above, the targets of climate hypocrisy across the entire sample were relatively evenly divided between individuals and institutions (including their representatives), with slightly more criticism of the latter than the former. We coded for attacks on five specific target types - three individual (environmentalists, cultural celebrities and politicians) and two institutional (governments/political parties and corporations) - as well as more general claims that 'everyone' is a hypocrite with respect to climate change. Politicians who were attacked for their lifestyle or personal behaviour (e.g. flying to a climate summit) were coded as 'politician'; however, if a politician was criticized for hypocritical political statements and/or actions (e.g. advocating climate action while simultaneously advancing policies to expand the fossil fuel industry), the target was coded as government/political party. Individuals associated with multiple categories were assigned to their most prominent identity (e.g. Al Gore was coded as an environmentalist, not a politician).

As Figure 6 [insert Figure 6 here] illustrates, target type was strongly associated with an item's orientation to climate change. Items which challenged the need for action predictably emphasized the hypocrisy of environmentalists. But a much larger number of items - which affirmed the need for more aggressive institutional measures - identified governments and 
political leaders as the real hypocrites on climate change. And while attacks against ecocelebrities were often quite intense, they were not especially prevalent as compared to environmentalists and governments. Corporate hypocrisy received little attention, perhaps because of the way hypocrisy discourse lends itself to identifying individual targets to attack.

We also tracked all accusations directed against specific 'named' targets. Figure 7 [insert Figure 7 here] shows the top 10 individual targets across the whole sample (with each target directly attacked in in twenty or more items). By a wide margin the most vilified figure in the sample was $\mathrm{Al}$ Gore. In addition to receiving far greater critical attention than any other individual or institution (almost three times more than the second most prominent individual target, former Australian Prime Minister Kevin Rudd), Gore was the only individual 'hypocrite' to appear in multiple papers from every region. Indeed, with the exception of Gore (and Live Earth, a global series of concerts designed to raise awareness about climate change), the principal 'named' targets were largely confined to particular regions. The only cultural celebrity who approached double digits was actress Cate Blanchett, who was criticized for championing the introduction of a carbon tax in Australia while practicing a highly carbon-intensive lifestyle. In terms of regional differences, accusations of hypocrisy in Australian papers were particularly heavily concentrated upon a few key individuals - Gore, Rudd, former PM Julia Gillard, former Green Party leader Bob Brown and climate scientist/activist Tim Flannery - while Canadian papers were most focused upon institutional targets, including the federal Liberal party which was widely criticized for not only its own failure to act, but its subsequent hypocrisy in attacking Conservative governments for their inaction.

As Table 3 [insert Table 3 here] illustrates, targeted behaviours in the overall sample were 18 
roughly evenly divided between individual lifestyle and political actions such as regulations, subsidies and other forms of institutional behaviour. Significant differences emerge, however, when one considers both region and orientation to climate change. In particular, items with a clear pro-climate perspective were far more likely to finger institutional behaviour as the problem while anti-climate and 'balanced' items prioritized the actions of individuals. Both Canadian and, to a somewhat lesser extent, Australian sources, had a much stronger focus upon institutions as compared to the United Kingdom and the United States which were evenly split. With respect to specific individual behaviours, flying and, in particular, 'luxury' consumption (e.g. private jets, mansions and multiple homes, yachts) attracted the most significant attention. The association of flight with climate hypocrisy was particularly strong in the UK papers (appearing in more than one-third of all items), focused principally on the controversy over the expansion of Heathrow airport. Considerations of diet - arguably the behaviour which is easiest for individuals to control and change - were almost entirely absent in the overall sample.

\section{$\underline{\text { Negative affect }}$}

Accusations of hypocrisy are often delivered in morally charged language intended to communicate and to cultivate outrage, disgust and antipathy towards the target. We coded for the presence of three different levels of negative affective intensity: significant, in which passionate, emotive, visceral language is used to denigrate, embarrass and condemn the credibility and integrity of an individual or institution; modest, in which the diagnosis of hypocrisy is framed as an invitation for normative judgement on the part of the reader/public but there is little inflammatory rhetoric; and minimal, in which allegations of hypocrisy are presented in a neutral, 
detached and primarily descriptive manner. Almost $40 \%$ of items were characterized by significant levels of negative affect; a slightly larger proportion possessed modest affect with a relatively small number of pieces with minimal negative affect.

As Figure 8 [insert Figure 8 here] illustrates, items invoking hypocrisy to criticize climate action were far more likely than pro-climate items to use language designed to invite a strong emotional response. Over $70 \%$ of anti-climate items were coded as having strong levels of negative affect, compared to less than $20 \%$ of pro-climate items. While a significant proportion of pro-climate items (23\%) adopted a neutral, descriptive style to report on climate hypocrisy, this more detached perspective was almost completely absent (2.9\%) in anti-climate items. Overall, just under half of all items targeting individuals (47.8\%) used strong emotional language as compared to less than a third (29.5\%) of those items criticizing institutions. However, as Table 4 [Insert Table 4 here] shows, items making the case against climate action consistently condemned the hypocrisy of both individuals and institutions with much greater passion and emotional intensity than those advocating a more aggressive response.

Unsurprisingly, items emphasizing opinion and argument (columns, editorials and letters-tothe-editor) were more likely to adopt an emotional, judgmental tone than news items in which journalists are bound by professional conventions emphasizing objectivity, neutrality and bipartisanship. Where less than $20 \%$ of news items were coded as possessing strong affect, over half of all columns (54.7\%), letters (53.0\%) and editorials (52.4\%) fell into this category. More striking is the extent to which conservative columnists - especially those which devoted significant attention to this issue - adopted a harsh, caustic and often mocking tone in ridiculing the hypocrisy of climate advocates as compared to the relative absence of such moralizing 20 
commentary among those criticizing the failures of governments and political leaders to fulfil their promises and commitments. When conservative columnists write about climate hypocrisy they almost always do so in a passionate language that invites their readers to attach feelings of outrage and disgust to those climate advocates whose actions fail to match their values and beliefs. Progressive, pro-climate action columnists, in contrast, are much more likely to remain on the more abstract terrain of structural, institutional and policy analysis, criticizing the contradictions between rhetoric and (political) action but broadly eschewing the moralized language that gives the concept of hypocrisy affective force and intensity.

\section{Type of hypocrisy discourse}

Finally, we coded for the presence of three distinct types of hypocrisy discourse in each item: personalized hypocrisy, which involves an explicitly moralized attack on the character and integrity of an individual based upon alleged inconsistencies between their beliefs and their (in)action; institutional-analytic hypocrisy, which primarily targets the contradiction between an institution's commitments around climate change and a failure to implement measures that reflect those commitments; and reflexive hypocrisy, which critically reflects upon hypocrisy discourse itself and usually challenges the simplistic, judgmental tone of such accusations and/or explores the structural factors which mediate the gap between values and actions. Initially, we expected that personalized hypocrisy would dominate our sample; however, institutional-analytic hypocrisy was actually more common. As Table 5 [insert Table 5 here] shows, the latter form was present in $60.9 \%$ of all items while the former appeared in $49.2 \%$ of the overall sample. Reflexive hypocrisy, in contrast, had a much smaller footprint, appearing in less than $15 \%$ of 
items.

As Table 5 also illustrates, the association of different forms of hypocrisy discourse with proand anti-climate action items was highly uneven. In items arguing against more aggressive mitigation measures, personalized hypocrisy was dominant, present in close to three-quarters of items as compared to institutional-analytic which appeared in less than half of such pieces. Sympathetic, reflexive accounts of hypocrisy were, unsurprisingly, almost entirely absent from such items. For pro-climate stories, this pattern was inverted: institutional-analytic hypocrisy appeared with much greater frequency $(72.7 \%)$ than personalized attacks $(27.3 \%)$. Indeed, reflexive explorations of hypocrisy were almost as common as personalized attacks in proclimate items, present in over $20 \%$ of such pieces. Regional variation was also quite significant. Canadian papers, for example, favoured institutional-analytic hypocrisy while Australian papers were just as likely to feature personalized attacks; in particular, criticism of political (in)action in the latter frequently attributed institutional hypocrisy to the moral failings of specific individuals such as former prime ministers Kevin Rudd and Julia Gillard.

Individual papers also diverged quite widely in terms of their emphasis upon different forms of climate hypocrisy. In both The Toronto Star and The Globe and Mail, for example, references to institutional-analytic hypocrisy outnumbered personalized hypocrisy by a margin of three to one and were present in close to $80 \%$ of each paper's items. The mirror opposite was the case in both The Sun and The Herald-Sun in which, respectively, $86 \%$ and $77 \%$ of all items referred to personalized hypocrisy with $38 \%$ and $48 \%$ of items discussing institutional-analytic hypocrisy. Figure 9 [insert Figure 9 here] shows the respective levels of emphasis upon reflexive and personalized hypocrisy by source, arranged by the ratio between them. The Guardian led the way 22 
in offering a reflexive account of climate hypocrisy with almost $30 \%$ of its items incorporating this perspective; indeed, The Guardian was the only paper in the sample in which reflexive was more common than personalized hypocrisy. The Globe and Mail, Toronto Star and New York Times each featured a significant number of items with a reflexive component, meaning that items containing personalized attacks were consistently leavened by pieces that offered a more critical, nuanced account of hypocrisy. The other papers featured either little (in the case of The National Post, The Australian and the UK Telegraph) or no (the Australian Telegraph, The Herald-Sun, The Wall Street Journal and The Sun) items containing a reflexive element.

\section{Discussion and Conclusion}

We started our research with a hunch that a more systematic review of climate hypocrisy discourse would reveal some surprises, but nevertheless assumed that personalized attacks on climate advocates (especially eco-celebrities and activists) would dominate our findings. This turned out not to be the case. Instead, the most pervasive form of hypocrisy discourse was an institutional-analytic variety that indicted governments (and politicians) for contradictions between what they say and do in terms of climate policy. And, even more surprising to us, climate hypocrisy was most frequently invoked (in our sample) to make the case for more aggressive action to mitigate climate change, suggesting that the rhetorical force of hypocrisy can be just as easily deployed to condemn structural, political inaction as personal behavioural complicity.

One must, however, exercise caution in making generalizations about climate hypocrisy discourse as one of the most striking (if not altogether unexpected) findings of this study is the 
compartmentalized, insular and starkly polarized visions of climate hypocrisy that unfold in different venues. Two broad clusters of hypocrisy discourse emerged as dominant in the overall sample: on the one hand, there was a pro-climate action variant focused upon institutions (which accounted for $32.3 \%$ of all items); and, on the other hand, there was an anti-climate action variant that targeted individual behaviour (which accounted for $25.9 \%$ of all items). While there was a rough parity between these two discursive clusters, there was a strong divergence between them within individual newspapers (see Table 6 [insert Table 6 here]). Only two of the twelve papers - the Washington Post and the Australian had a similar 'balanced' ratio between these two clusters: all of the other sources heavily favoured one or the other discursive form.

Drawing upon other elements of our coding schematic, one can begin to constellate additional features of pro- and anti-climate formations of climate hypocrisy. Pieces in the former camp are tend to focus upon the duplicitous behaviour of institutions, are far more likely to appear in news or feature sections, accept the scientific consensus on global warming and adopt a detached and analytic mode of presentation. This is a space for structural criticisms of state and economy as defined by an emphasis upon climate policy, a critique of political discourse as public relations and attention to the contradictions between capitalist political economy and ecological sustainability. Conversely, items in the latter camp target individuals for their personal lifestyle choices, tend to be authored by a select group of columnists and editorial boards, refer directly or indirectly to climate change denial, define behavioural choices as the prime driver of social change and use an inflammatory rhetorical style intended to solicit moral judgment, condemnation and outrage. There one will find decadent celebrities, hypocritical environmentalists and political charlatans held to account and presented as the avatars of a 24 
creeping ecological authoritarianism.

Where the former discourse is often diffuse and fragmented, scattered amidst a broad variety of news and commentary, the latter tends to be highly concentrated and condensed, rich with evocative vignettes that amplify populist clichés about liberal elites. These anecdotes are often skilfully integrated into well-crafted, affectively intense populist parables about environmentalism as a sanctimonious conspiracy to deprive us of our freedoms. Elsewhere we explore this dynamic at greater length (Gunster et. al. 2017), but we suspect that the much stronger narrative consistency, ideological coordination and affective intensity that characterizes conservative accounts of climate hypocrisy may give these accounts a discursive resonance and 'stickiness' that exceeds their quantitative significance. Anti-climate hypocrisy, then, may be less frequent but ultimately more memorable and compelling as a means of thinking and feeling about climate change. Beyond the appeal of such discourse to those who are already politically, ideologically and/or economically inclined to dismiss the need for climate action, such arguments may also have an oversized impact in terms of shaming and silencing those who feel the tension between ecologically-minded aspirations and the carbon intensive behaviours and choices that structure contemporary life for many.

These two constellations reflect well how Hulme (2010) in particular argues that climate discourse is always read in relation to pre-existing cultural ideologies, structuring climate change as irreducibly conflictual. But the most fertile (and imperative) form of climate hypocrisy, potentially breaking with this conflictual logic, may ultimately be what we have described as reflexive hypocrisy, which was also the most under-developed form in our sample. Much of the sound and fury of climate hypocrisy - for both opponents and advocates of climate action - is 
driven by the rhetorical objective of attacking, condemning and ridiculing one's opponents. However, the more interesting (and pressing) challenge posed by climate hypocrisy may well be how to understand it as a general condition, that is, as something that affects virtually everyone (at least in the global North). For all their moralizing bluster, conservatives are actually quite comfortable with both personal and institutional climate hypocrisy precisely because it confirms an ideological worldview that actors are driven by self-interest, and that this is normatively a good thing. Progressive accounts that simply replace individual with institutional targets, denouncing governments for their failure to live up to their climate rhetoric, risks tipping into the cynical, complacent and ultimately conservative affirmation that inaction on climate change is inevitable because politicians never keep their promises (Gunster 2011). Reflexive hypocrisy, in contrast, promises a much more productive tension between the inescapable moral responsibility that carbon intensive lifestyles necessarily impose and the impossibility of discharging this responsibility through consumer choice alone. It embraces the messiness of the cultural politics of climate change as outlined at the beginning of this article - the complex interplay between devices, desires and dissent (Bulkeley et al. 2016) entailed by seeking low-carbon social change. As such it has the potential to enable climate change discourse to speak across the polarizing divides represented by the other two forms of discourse. Imagining and nurturing communicative spaces, forms of subjectivity, social and political practices and institutions through which we can think and talk about our shared climate hypocrisy - how it makes us feel and what we can do, individually and collectively, to address it - may be the most significant contribution this discourse has to offer to motivating a stronger and deeper engagement with climate change. 


\section{References}

Anderson, A. (2011). Sources, media, and modes of climate change communication: the role of celebrities. Wiley Interdisciplinary Reviews: Climate Change. 2 (4), 535-546.

Attari, S. Z., Krantz, D. H., and Weber, E. U. (2016). Statements about climate researchers' carbon footprints affect their credibility and the impact of their advice. Climatic Change $138,325-338$.

Barr, S., (2011). Climate forums: virtual discourses on climate change and the sustainable lifestyle. Area 43 (1), 14-22.

Boykoff, M. T. (2011). Who speaks for the climate? Making sense of media reporting on climate change. New York: Cambridge University Press.

Boykoff, M. T., \& Goodman, M. K., (2009). Conspicuous redemption? Reflections on the promises and perils of the 'Celebritization' of climate change. Geoforum 40 (3), 395-406.

Brunsson, N. (1989). The organization of hypocrisy: Talk, decisions and actions in organizations. Chichester: John Wiley \& Sons.

Bulkeley, H., Paterson, M., and Stripple, J. (eds)., (2016). Towards a Cultural Politics of Climate Change. Cambridge: Cambridge University Press.

Carvalho, A. (2007). Ideological cultures and media discourses on scientific knowledge: rereading news on climate change. Public Understanding of Science 16 (2), 223-243.

Carvalho, A. (2010). Media(ted) discourses and climate change: a focus on political subjectivity and (dis)engagement. Wiley Interdisciplinary Reviews: Climate Change 1 (2), 172-179.

Cho, C. H., Laine, M., Roberts, R. W., and Rodrigue, M. (2015). Organized hypocrisy, organizational facades, and sustainable reporting. Accounting, Organizations and Society 40, 78-94.

Cooper, G., Green, N., Burningham, K., Evans, D., and Jackson, T., (2012). Unravelling the threads: Discourses of sustainability and consumption in an online forum. Environmental Communication 6 (1), 101-118.

Crow, D. A., and Boykoff, M. T., (2014). Culture, Politics and Climate Change: How Information Shapes Our Common Future. New York: Routledge.

Dannenberg, C. J., Hausman, B. L., Lawrence, H. Y., and Powell, K. M., (2012). The moral appeal of environmental discourses: The implication of ethical rhetorics. Environmental Communication 6 (2), 212-232.

Dryzek, J. (2005). The Politics of the Earth: Environmental Discourses, 2nd Edition. Oxford: Oxford University Press.

Eckersley, R., (2013). Poles apart?: The social construction of responsibility for climate change in Australia and Norway. Australian Journal of Politics and History 59 (3), 382-396.

Elsasser, S. W., and Dunlap. R. E., (2013). Leading Voices in the Denier Choir: Conservative Columnists' Dismissal of Global Warming and Denigration of Climate Science. American Behavioral Scientist 57, 754-76.

Gavin, N. T. and Marshall, T., (2011). Mediated climate change in Britain: Scepticism on the web and on television around Copenhagen. Global Environmental Change 21, 10351044. 
Gunster, S., (2011). Covering Copenhagen: Climate politics in B.C. media. Canadian Journal of Communication, 36 (3), 477-502.

Gunster, S., Fleet, D., Paterson, M., and Saurette, P., (2017). From outrage to cynicism, from lifestyle to politics: Competing visions of climate hypocrisy. Delivered to the Environmental Studies Association of Canada Annual Conference, Toronto, June.

Gunster, S., and Saurette, P., (2014). Storylines in the Sands: News, Narrative, and Ideology in the Calgary Herald. Canadian Journal of Communication 39 (3), 333-359.

Hackett, B., Forde, S., Gunster, S. and Foxwell-Norton, K. (2017). Journalism and Climate Crisis: Public Engagement, Media Alternatives. New York: Routledge.

Hajer, M. (1995). The Politics of Environmental Discourse: Ecological Modernisation and the Policy Process. Oxford: Clarendon.

Höijer, B. (2010). Emotional anchoring and objectification in the media reporting on climate change. Public Understanding of Science 19 (6), 717-731.

Höppner, C., (2010). Rereading public opinion polls on climate change in the UK press. International Journal of Communication 4, 977-1005.

Huertas, A. and Adler, D., (2012). Is News Corp. failing science? Representations of climate science on Fox News Channel and in the Wall Street Journal opinion pages. Union of Concerned Scientists (September). Retrieved from: http://www.jstor.org/stable/resrep00040, 31p.

Hulme, M. (2010). Why We Disagree About Climate Change. Cambridge: Cambridge University Press.

Jamieson, K. H. and Cappella, J. N., (2008). Echo Chamber: Rush Limbaugh and the Conservative Media Establishment. Oxford: Oxford University Press.

Knight, G., and Greenberg, J., (2011). Talk of the enemy: Adversarial framing and climate change discourse. Social Movement Studies: Journal of Social, Cultural and Political Protest 10 (4), 323-340.

Laidley, T. (2013). Climate, class and culture: political issues as cultural signifiers in the US. The Sociological Review 61, 153-171.

Marshall, G., (2014). Don't even think about it: Why our brains are wired to ignore climate change. New York: Bloomsbury.

Mayer, F. W., (2012). Stories of climate change: Competing narratives, the Media, and U.S. public opinion, 2001-2010. Discussion Paper, Joan Shorenstein Center on the Press, Politics and Public Policy, 47p.

McComas, K. and Shanahan, J., (1999). Telling stories about global climate change: Measuring the impact of narratives on issue cycles. Communication Research 26 (1), 30-57.

McGregor, C., (2015). Direct climate action as public pedagogy: the cultural politics of the Camp for Climate Action. Environmental Politics 24 (3), 343-362.

News Corp., (n.d.). Our Businesses. https://newscorp.com/about/our-businesses/, accessed 17 January 2018.

Nisbet, M. (2009). Communicating climate change: Why frames matter for public engagement. Environment: Science and Policy for Sustainable Development 51 (2), 12-23.

Norgaard, K. M. (2011). Living in Denial: Climate Change, Emotions, and Everyday Life. Cambridge MA: MIT Press. 
Oreskes, N. and Conway, E. M., (2011). Merchants Of Doubt, New York: Bloomsbury.

Platt, R., and Retallack, S., (2009). Consumer power: How the public thinks lower-carbon behaviour could be made mainstream. Institute for Public Policy Research, 47p.

Schneider, J., Schwarze, S., Peeples, J., and Bsumek, P., (2016). Under pressure: coal industry rhetoric and neoliberalism. London: Palgrave Macmillan.

Song, L., (2016). Climate scientists' personal carbon footprints come under scrutiny. Inside Climate News (June 23). Retrieved from: https://insideclimatenews.org/news/23062016/climate-scientists-say-practicing-whatthey-preach-helps-credibility-global-warming-carbon-footprint

Webb, J., (2012). Climate Change and Society: The Chimera of Behaviour Change Technologies. Sociology 46 (1), 109-125.

Urry, J. (2011). Climate Change and Society. Malden, MA: Polity.

Watts, A. (2016). Study: 'Climate scientists are more credible when they practice what they preach' - but my aerial surveys show many don't. Watts Up With That. (June 16). Retrieved from: https://wattsupwiththat.com/2016/06/16/study-climate-scientists-aremore-credible-when-they-practice-what-they-preach-but-my-aerial-surveys-show-manydont/

Yoder, K. (2016). People don't trust hypocritical climate scientists, study finds. Grist. (June 21). Retrieved from: http:/grist.org/climate-energy/people-dont-trust-hypocritical-climatescientists-study-finds/.

Young, N., (2011). Working on the fringes: The role of letters to the editor in advancing nonstandard media narratives about climate change. Public Understanding of Science 22 (4), 443-459. 
Table 1. Coding variables, definitions and values.

\begin{tabular}{|l|l|l|}
\hline Variable & Definition & Values \\
\hline $\begin{array}{l}\text { Climate change } \\
\text { orientation }\end{array}$ & $\begin{array}{l}\text { What position(s) does an item take } \\
\text { on the need for action to mitigate } \\
\text { climate change? }\end{array}$ & $\begin{array}{l}\text { Criticize action(s) to mitigate climate } \\
\text { change; support action(s) to mitigate } \\
\text { climate change; both; other. }\end{array}$ \\
\hline $\begin{array}{l}\text { Climate science } \\
\text { denial }\end{array}$ & $\begin{array}{l}\text { Does the item raise doubts about } \\
\text { the scientific basis of anthropogenic } \\
\text { climate change? }\end{array}$ & Present; absent. \\
\hline $\begin{array}{l}\text { Negative } \\
\text { affective } \\
\text { intensity }\end{array}$ & $\begin{array}{l}\text { What level of negative affect is } \\
\text { associated with the accusation of } \\
\text { hypocrisy? }\end{array}$ & Significant; modest; minimal. \\
\hline Type of target & $\begin{array}{l}\text { What type of target is accused of } \\
\text { hypocrisy? }\end{array}$ & $\begin{array}{l}\text { Individual(s); institution(s), including those } \\
\text { acting in an institutional role; both. }\end{array}$ \\
\hline $\begin{array}{l}\text { Particular target } \\
\text { actor }\end{array}$ & $\begin{array}{l}\text { Who/what are the specific actors } \\
\text { which are targeted? }\end{array}$ & $\begin{array}{l}\text { Environmentalists; politicians (as } \\
\text { individuals); cultural celebrities; } \\
\text { governments and/or political parties; } \\
\text { corporations; everyone (or human nature). }\end{array}$ \\
\hline $\begin{array}{l}\text { Type of target } \\
\text { behaviour }\end{array}$ & $\begin{array}{l}\text { What type of behaviour is described } \\
\text { as hypocritical? }\end{array}$ & $\begin{array}{l}\text { Consumptive and/or lifestyle; institutional } \\
\text { and/or structural practices. }\end{array}$ \\
\hline $\begin{array}{l}\text { Particular target } \\
\text { lifestyle } \\
\text { behaviour }\end{array}$ & $\begin{array}{l}\text { What specific lifestyle behaviours } \\
\text { are targeted? }\end{array}$ & $\begin{array}{l}\text { General emissions and/or energy usage; } \\
\text { flying; driving; diet; household consumption; } \\
\text { luxury consumption (i.e. forms of } \\
\text { consumption framed as extravagant and/or } \\
\text { exceeding social norms such as the use of a } \\
\text { private jet). }\end{array}$ \\
\hline Target event & $\begin{array}{l}\text { Are specific events associated with } \\
\text { climate hypocrisy? }\end{array}$ & $\begin{array}{l}\text { International climate summits; LiveEarth } \\
\text { concert; Earth Day. }\end{array}$ \\
\hline
\end{tabular}


Table 2. Ideological clustering as defined by orientation to action on climate change.

\begin{tabular}{||l||l|l|l|l|l|l||}
\hline Newspaper & $\begin{array}{l}\text { Anti climate } \\
\text { action }\end{array}$ & $\begin{array}{l}\text { Pro climate } \\
\text { action }\end{array}$ & Both & Other & Total & Ratio* \\
\hline \hline National Post (Can) & 94 & 18 & 12 & 5 & 129 & 5.2 \\
\hline Herald-Sun (Aus) & 54 & 11 & 17 & 4 & 86 & 4.9 \\
\hline Telegraph (Aus) & 30 & 10 & 15 & 6 & 61 & 3 \\
\hline Wall Street Journal (US) & 15 & 5 & 2 & 3 & 25 & 3 \\
\hline Sun (UK) & 16 & 9 & 3 & 1 & 29 & 1.8 \\
\hline The Australian (Aus) & 42 & 34 & 47 & 4 & 127 & 1.2 \\
\hline Telegraph (UK) & 30 & 27 & 6 & 3 & 66 & 1.1 \\
\hline Conservative & $\mathbf{2 8 1}$ & $\mathbf{1 1 4}$ & $\mathbf{1 0 2}$ & $\mathbf{2 6}$ & $\mathbf{5 2 3}$ & $\mathbf{2 . 5}$ \\
& $\mathbf{( 5 3 . 7 \% )}$ & $\mathbf{( 2 1 . 8 \% )}$ & $\mathbf{( 1 9 . 5 \% )}$ & $\mathbf{( 4 . 9 \% )}$ & $\mathbf{( 1 0 0 \% )}$ & \\
\hline Washington Post (US) & 14 & $\mathbf{2 6}$ & 3 & 1 & 44 & 1.9 \\
\hline Globe \& Mail (Can) & 14 & 55 & 6 & 3 & 78 & 3.9 \\
\hline New York Times (US) & 2 & $\mathbf{2 8}$ & 6 & 3 & 39 & 14 \\
\hline Toronto Star (Can) & $\mathbf{2}$ & $\mathbf{4 5}$ & $\mathbf{7}$ & $\mathbf{2}$ & 56 & 22.5 \\
\hline Guardian (UK) & $\mathbf{2}$ & $\mathbf{1 2 8}$ & 19 & 3 & 152 & 64 \\
\hline Progressive & $\mathbf{3 4}$ & $\mathbf{2 8 2}$ & $\mathbf{4 1}$ & $\mathbf{1 2}$ & $\mathbf{3 6 9}$ & $\mathbf{8 . 5}$ \\
\hline \hline Total & $\mathbf{( 9 . 2 \% )}$ & $\mathbf{7 6 . 4 \% )}$ & $\mathbf{( 1 1 . 1 \% )}$ & $\mathbf{( 3 . 3 \% )}$ & $\mathbf{( 1 0 0 \% )}$ & \\
\hline \hline
\end{tabular}

* Refers to ratio of anti- to pro-climate action items for conservative papers and the reverse for progressive papers. 
Table 3. Targeted behaviours by region and orientation to climate change.

\begin{tabular}{|c|c|c|c|c|c|c|c|c|}
\hline & \multicolumn{4}{|c|}{ Paper region } & \multicolumn{3}{|c|}{$\begin{array}{l}\text { Item orientation to climate } \\
\text { action }\end{array}$} & \multirow[t]{2}{*}{ Total } \\
\hline & CAN & US & UK & AUS & $\begin{array}{l}\text { Anti- } \\
\text { action }\end{array}$ & $\begin{array}{l}\text { Pro- } \\
\text { action }\end{array}$ & Both/other & \\
\hline $\begin{array}{l}\text { Individual- } \\
\text { lifestyle }\end{array}$ & $\begin{array}{l}101 \\
(38.4 \%)\end{array}$ & $\begin{array}{l}61 \\
(56.5 \%)\end{array}$ & $\begin{array}{l}138 \\
(55.9 \%)\end{array}$ & $\begin{array}{l}119 \\
(43.4 \%)\end{array}$ & $\begin{array}{l}179 \\
(56.8 \%)\end{array}$ & $\begin{array}{l}150 \\
(37.9 \%)\end{array}$ & $\begin{array}{l}90 \\
(49.7 \%)\end{array}$ & $\begin{array}{l}419 \\
(47.0 \%)\end{array}$ \\
\hline $\begin{array}{l}\text { Institutional- } \\
\text { political }\end{array}$ & $\begin{array}{l}181 \\
(68.8 \%)\end{array}$ & $\begin{array}{l}59 \\
(54.6 \%)\end{array}$ & $\begin{array}{l}132 \\
(53.4 \%)\end{array}$ & $\begin{array}{l}168 \\
(61.3 \%)\end{array}$ & $\begin{array}{l}146 \\
(46.3 \%)\end{array}$ & $\begin{array}{l}288 \\
(72.7 \%)\end{array}$ & $\begin{array}{l}106 \\
(58.6 \%)\end{array}$ & $\begin{array}{l}540 \\
(60.5 \%)\end{array}$ \\
\hline Flying & 37 & 20 & 84 & 65 & 100 & 70 & 36 & 206 \\
\hline Luxury & 41 & 29 & 56 & 61 & 98 & 53 & 36 & 187 \\
\hline Driving & 41 & 18 & 38 & 40 & 52 & 56 & 29 & 137 \\
\hline Household & 20 & 19 & 14 & 33 & 52 & 21 & 13 & 86 \\
\hline $\begin{array}{l}\text { General } \\
\text { emissions }\end{array}$ & 19 & 7 & 19 & 11 & 14 & 25 & 17 & 56 \\
\hline Diet & 9 & 3 & 15 & 7 & 15 & 12 & 7 & 34 \\
\hline Total items & 263 & 108 & 247 & 274 & 315 & 396 & 181 & 892 \\
\hline
\end{tabular}

* Note: multiple behaviour types and specific behaviours may be present in the same item. 
Table 4. Intensity of negative affect by orientation to climate change and target type.

\begin{tabular}{|l||l|l|l|l|l|l||}
\hline \multirow{2}{*}{$\begin{array}{l}\text { Intensity of } \\
\text { negative } \\
\text { affect }\end{array}$} & Individual target & \multicolumn{2}{l||}{ Institutional target } \\
\cline { 2 - 7 } & Anti-climate & Pro-climate & Total & Anti-climate & Pro-climate & Total \\
\hline Significant & $118(74.2 \%)$ & $15(15.6 \%)$ & $133(52.2 \%)$ & $62(57.9 \%)$ & $45(18.1 \%)$ & $107(30.1 \%)$ \\
\hline Modest & $36(22.6 \%)$ & $46(47.9 \%)$ & $82(32.2 \%)$ & $42(39.3 \%)$ & $163(65.5 \%)$ & $205(57.6 \%)$ \\
\hline Minimal & $5(3.1 \%)$ & $35(36.5 \%)$ & $40(15.7 \%)$ & $3(2.8 \%)$ & $41(16.5 \%)$ & $44(12.4 \%)$ \\
\hline Total & $159(100 \%)$ & $96(100 \%)$ & $255(100 \%)$ & $107(100 \%)$ & $249(100 \%)$ & $356(100 \%)$ \\
\hline
\end{tabular}

* Note: table does not include items with both target types or items with both/other orientation to climate change. 
Table 5. Type of hypocrisy discourse by region and orientation to climate change.

\begin{tabular}{|c|c|c|c|c|c|c|c|c|}
\hline \multirow[t]{2}{*}{$\begin{array}{l}\text { Hypocrisy } \\
\text { type }\end{array}$} & \multicolumn{4}{|c|}{ Paper region } & \multicolumn{3}{|c|}{$\begin{array}{l}\text { Item orientation to climate } \\
\text { action }\end{array}$} & \multirow[t]{2}{*}{ Total } \\
\hline & CAN & US & UK & AUS & $\begin{array}{l}\text { Anti- } \\
\text { climate }\end{array}$ & $\begin{array}{l}\text { Pro- } \\
\text { climate }\end{array}$ & Both/other & \\
\hline Personalized & $\begin{array}{l}98 \\
(37.2 \%) \\
\end{array}$ & $\begin{array}{l}52 \\
(48.1 \%)\end{array}$ & $\begin{array}{l}113 \\
(45.7 \%)\end{array}$ & $\begin{array}{l}176 \\
(64.2 \%)\end{array}$ & $\begin{array}{l}231 \\
(73.3 \%)\end{array}$ & $\begin{array}{l}108 \\
(27.3 \%)\end{array}$ & $\begin{array}{l}100 \\
(55.2 \%)\end{array}$ & $\begin{array}{l}439 \\
(49.2 \%)\end{array}$ \\
\hline $\begin{array}{l}\text { Institutional- } \\
\text { analytic }\end{array}$ & $\begin{array}{l}183 \\
(69.6 \%) \\
\end{array}$ & $\begin{array}{l}58 \\
(53.7 \%)\end{array}$ & $\begin{array}{l}135 \\
(54.7 \%)\end{array}$ & $\begin{array}{l}167 \\
(60.9 \%)\end{array}$ & $\begin{array}{l}145 \\
(46 \%) \\
\end{array}$ & $\begin{array}{l}288 \\
(72.7 \%)\end{array}$ & $\begin{array}{l}110 \\
(60.8 \%)\end{array}$ & $\begin{array}{l}543 \\
(60.9 \%) \\
\end{array}$ \\
\hline Reflexive & $\begin{array}{l}35 \\
(13.3 \%) \\
\end{array}$ & $\begin{array}{l}18 \\
(16.7 \%)\end{array}$ & $\begin{array}{l}61 \\
(24.7 \%)\end{array}$ & $\begin{array}{l}15 \\
(5.1 \%) \\
\end{array}$ & $\begin{array}{l}5 \\
(1.6 \%) \\
\end{array}$ & $\begin{array}{l}87 \\
(22 \%) \\
\end{array}$ & $\begin{array}{l}36 \\
(19.9 \%)\end{array}$ & $\begin{array}{l}128 \\
(14.4 \%)\end{array}$ \\
\hline Total & 263 & 108 & 247 & 274 & 315 & 396 & 181 & 892 \\
\hline
\end{tabular}


Table 6. Pro-climate, institutional hypocrisy vs. anti-climate, personalized hypocrisy by paper

\begin{tabular}{|l||l|l||l|l||}
\hline \multirow{2}{*}{ Newspaper } & Pro-climate, institutional hypocrisy & \multicolumn{2}{l||}{ Anti-climate, personalized hypocrisy } \\
\cline { 2 - 5 } & Percent of items & $\begin{array}{l}\text { Difference from } \\
\text { sample means }\end{array}$ & Percent of items & $\begin{array}{l}\text { Difference from } \\
\text { sample means }\end{array}$ \\
\hline \hline Toronto Star & $64.3 \%$ & +32 & $3.6 \%$ & -22.3 \\
\hline New York Times & $59.0 \%$ & +26.7 & $2.6 \%$ & -23.3 \\
\hline Guardian & $57.9 \%$ & +25.6 & $1.3 \%$ & -24.6 \\
\hline Globe and Mail & $57.7 \%$ & +25.4 & $11.5 \%$ & -14.4 \\
\hline Washington Post & $31.8 \%$ & -0.5 & $29.6 \%$ & +3.7 \\
\hline Australian & $25.2 \%$ & -7.1 & $24.4 \%$ & -1.5 \\
\hline Telegraph (UK) & $24.2 \%$ & -8.0 & $37.9 \%$ & +12.0 \\
\hline Sun & $17.2 \%$ & -15.1 & $51.7 \%$ & +25.8 \\
\hline Wall Street Journal & $16.0 \%$ & -16.3 & $44.0 \%$ & +18.1 \\
\hline National Post & $10.1 \%$ & -22.2 & $39.5 \%$ & +13.6 \\
\hline Telegraph (Aus) & $9.8 \%$ & -22.5 & $41.0 \%$ & +15.1 \\
\hline Herald-Sun & $7.0 \%$ & -25.3 & $53.5 \%$ & +28.0 \\
\hline \hline Total & $32.3 \%$ & & $25.9 \%$ & \\
\hline
\end{tabular}


Figure 1. Ideological clusters as defined by orientation to action on climate change.

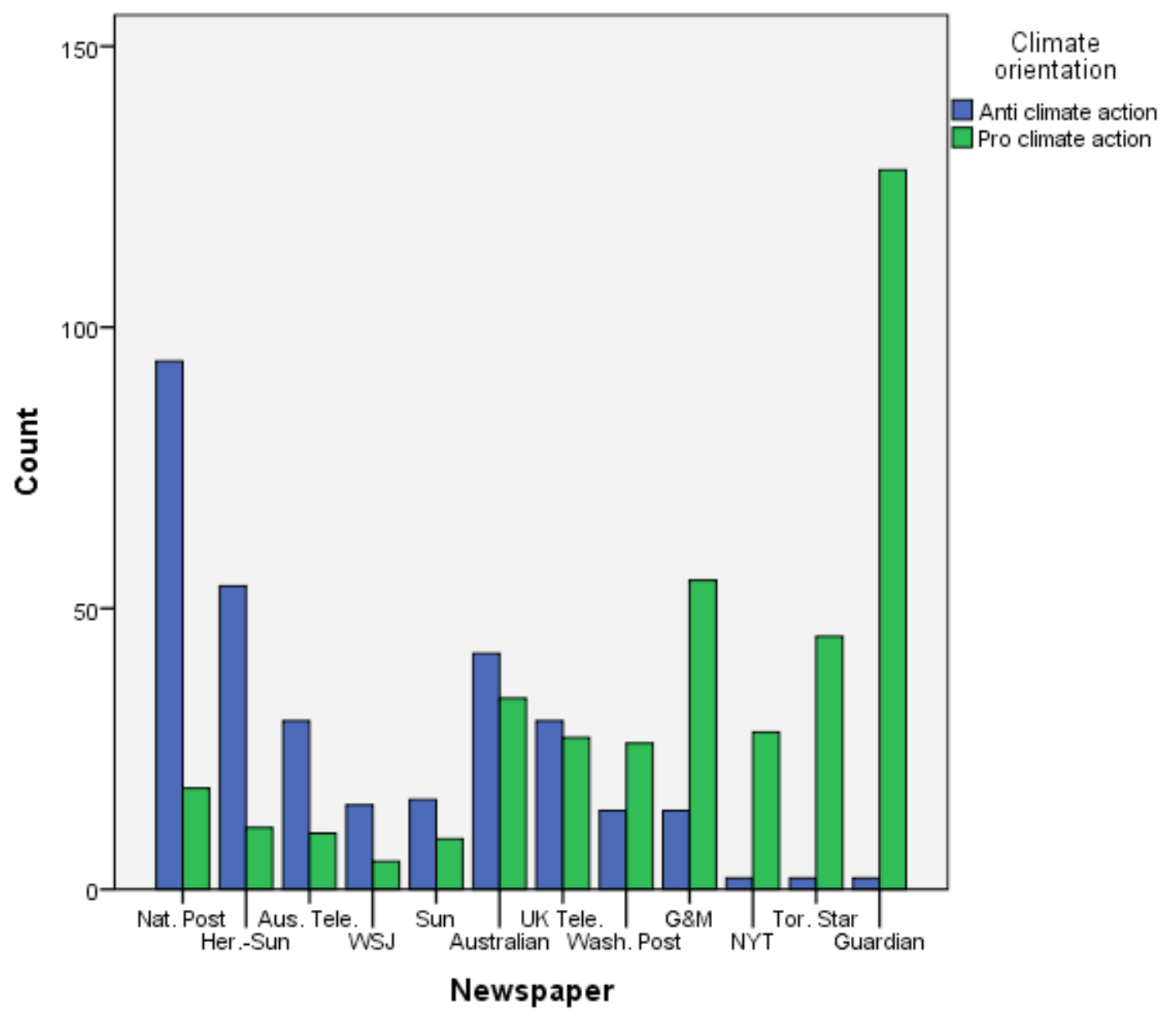


Figure 2. Item type in conservative papers by climate orientation.

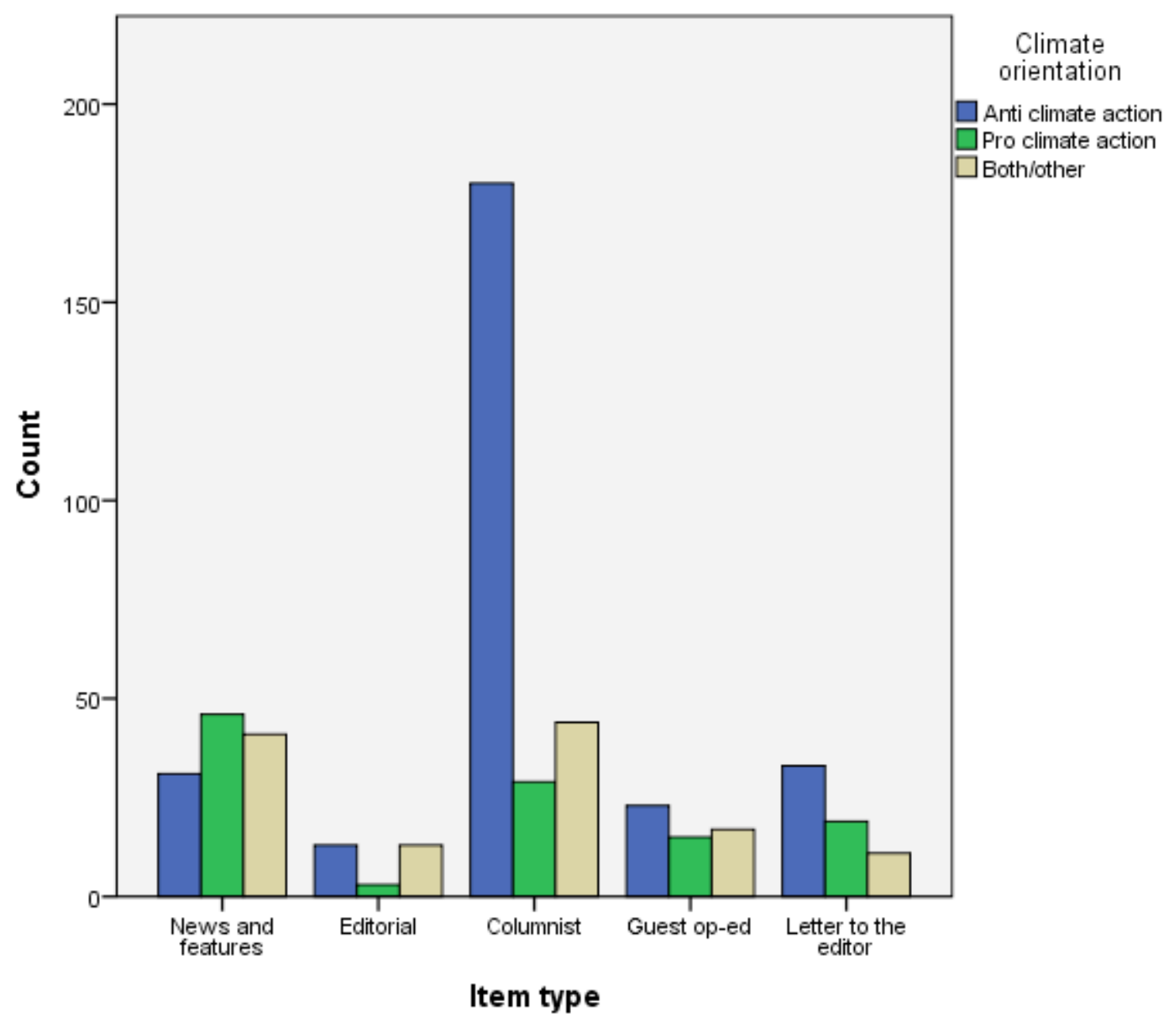

Note: does not include book excerpts, reviews and other items (5 of 523 items). 
Figure 3. Item type in progressive papers by climate orientation.

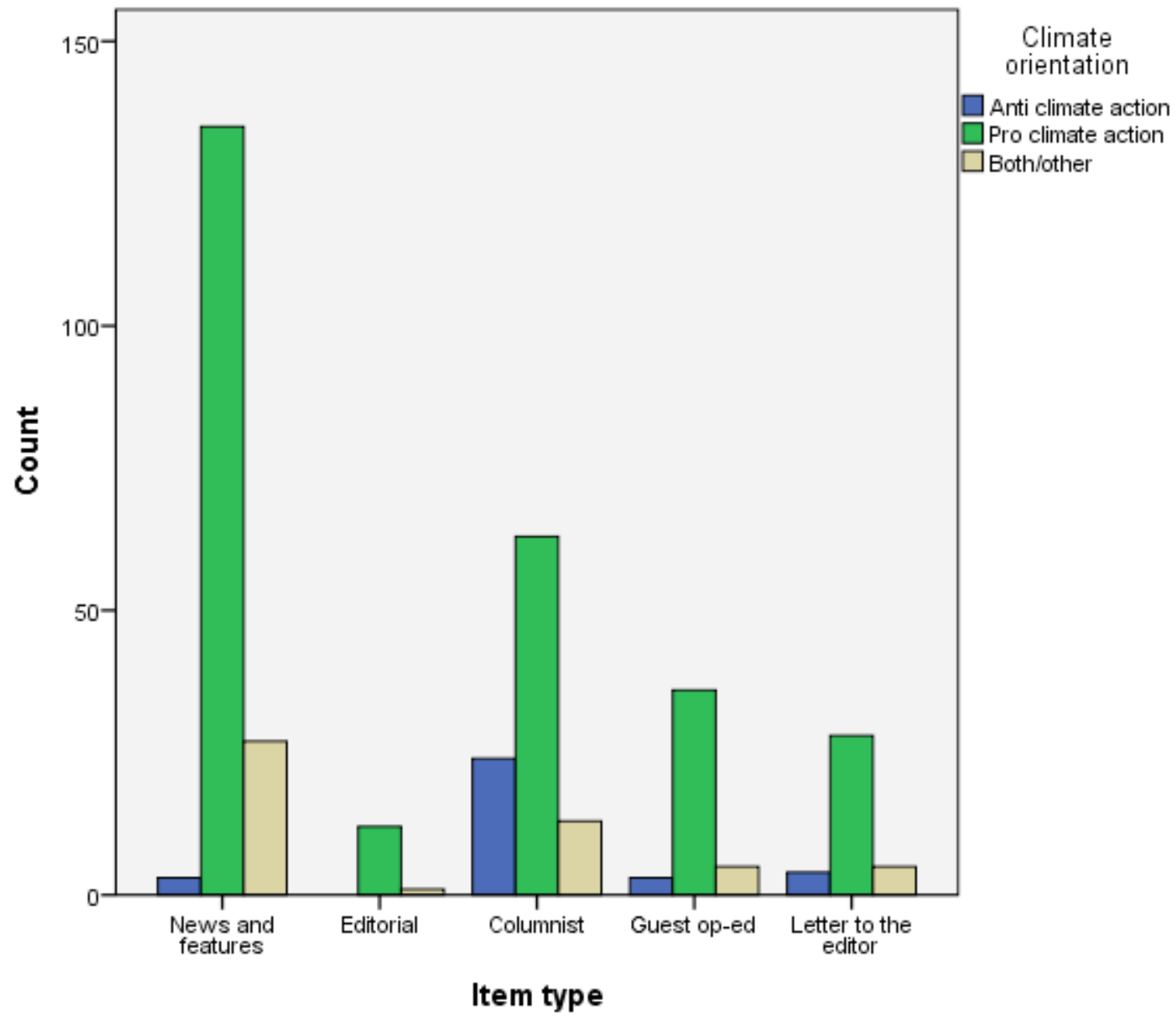

Note: does not include book excerpts, reviews and other items (10 of 369 items). 
Figure 4. Item type in all papers by climate orientation.

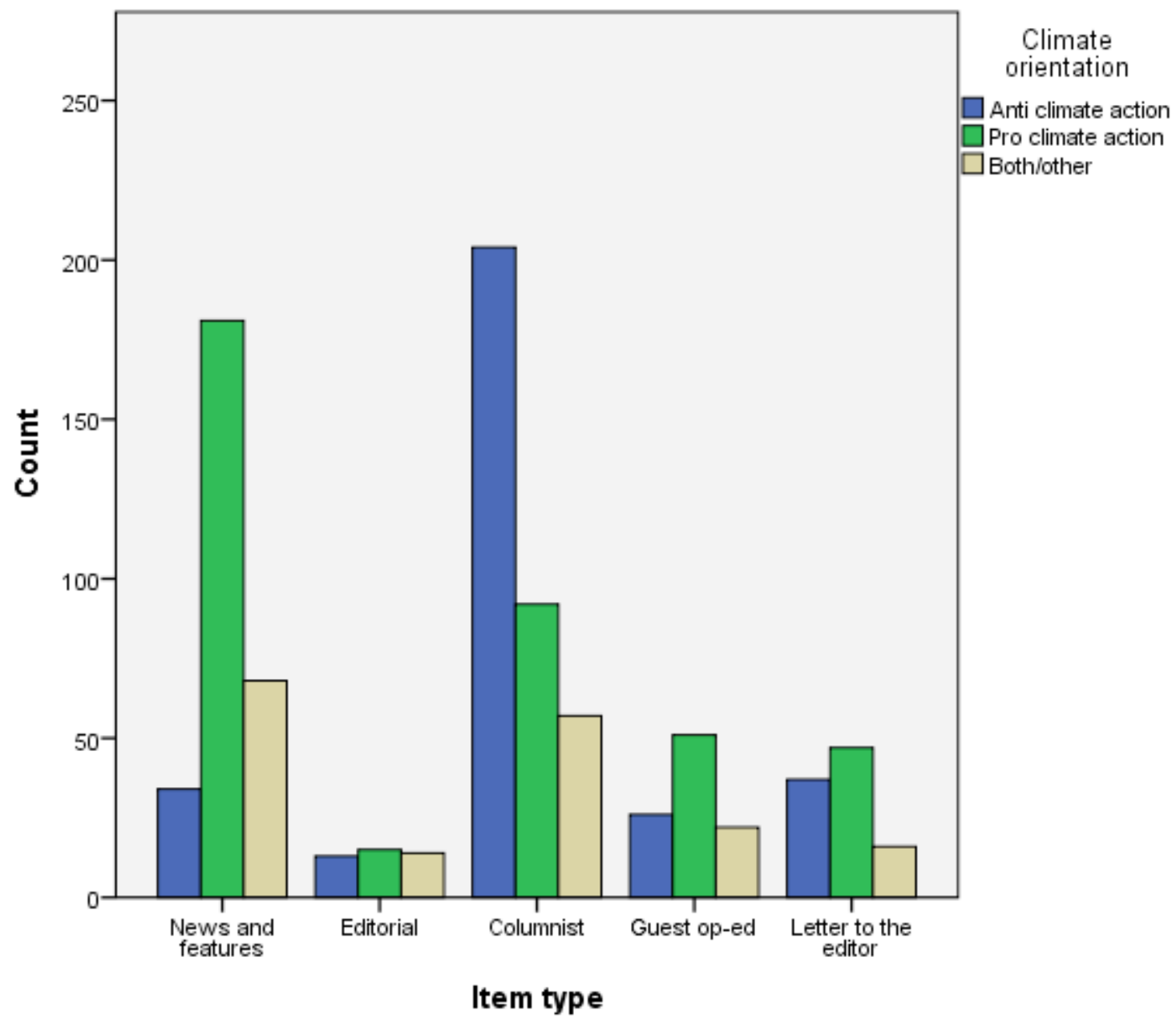


Figure 5. Climate denial by item type.

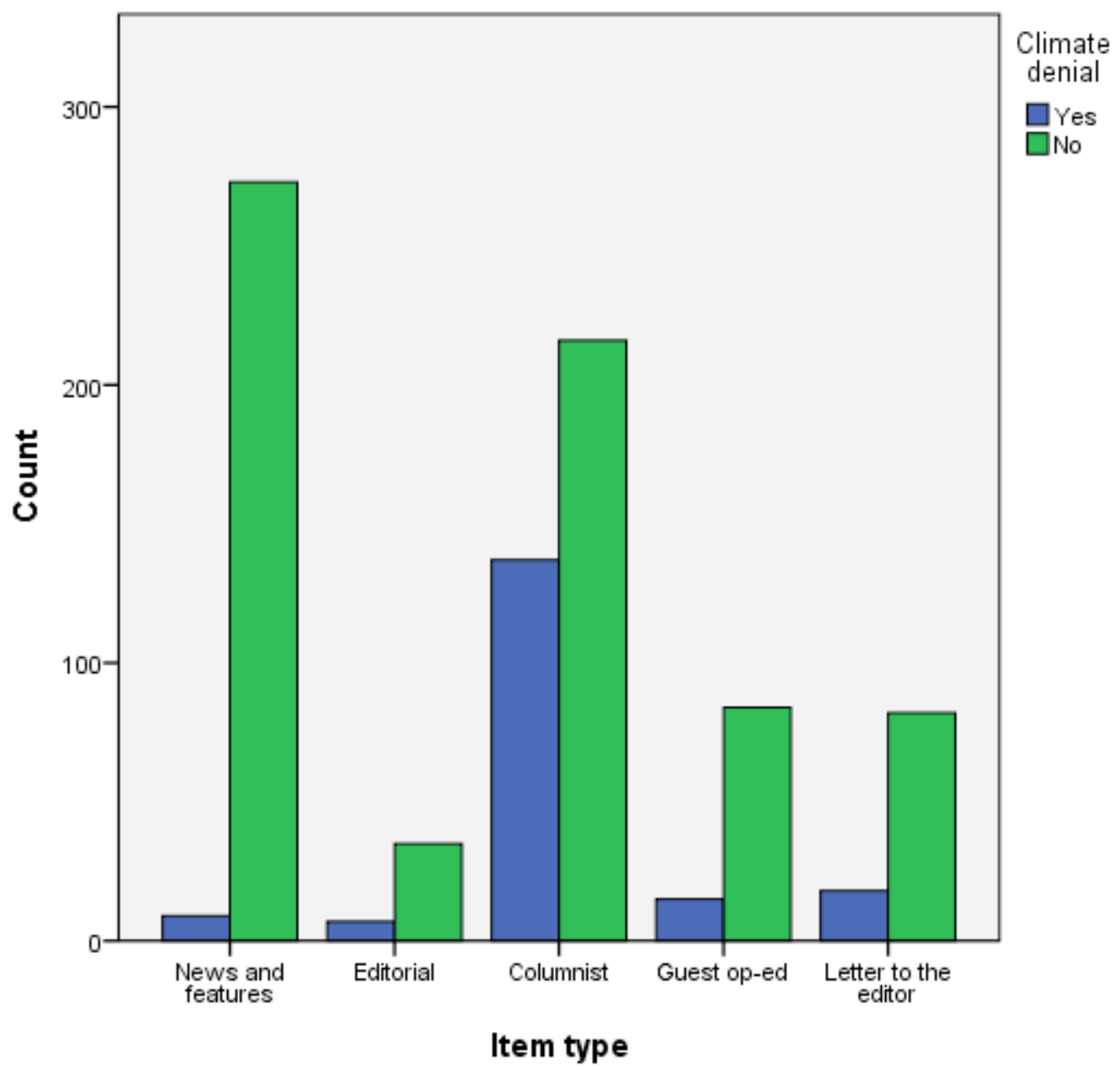


Figure 6. Target actor types by climate orientation.

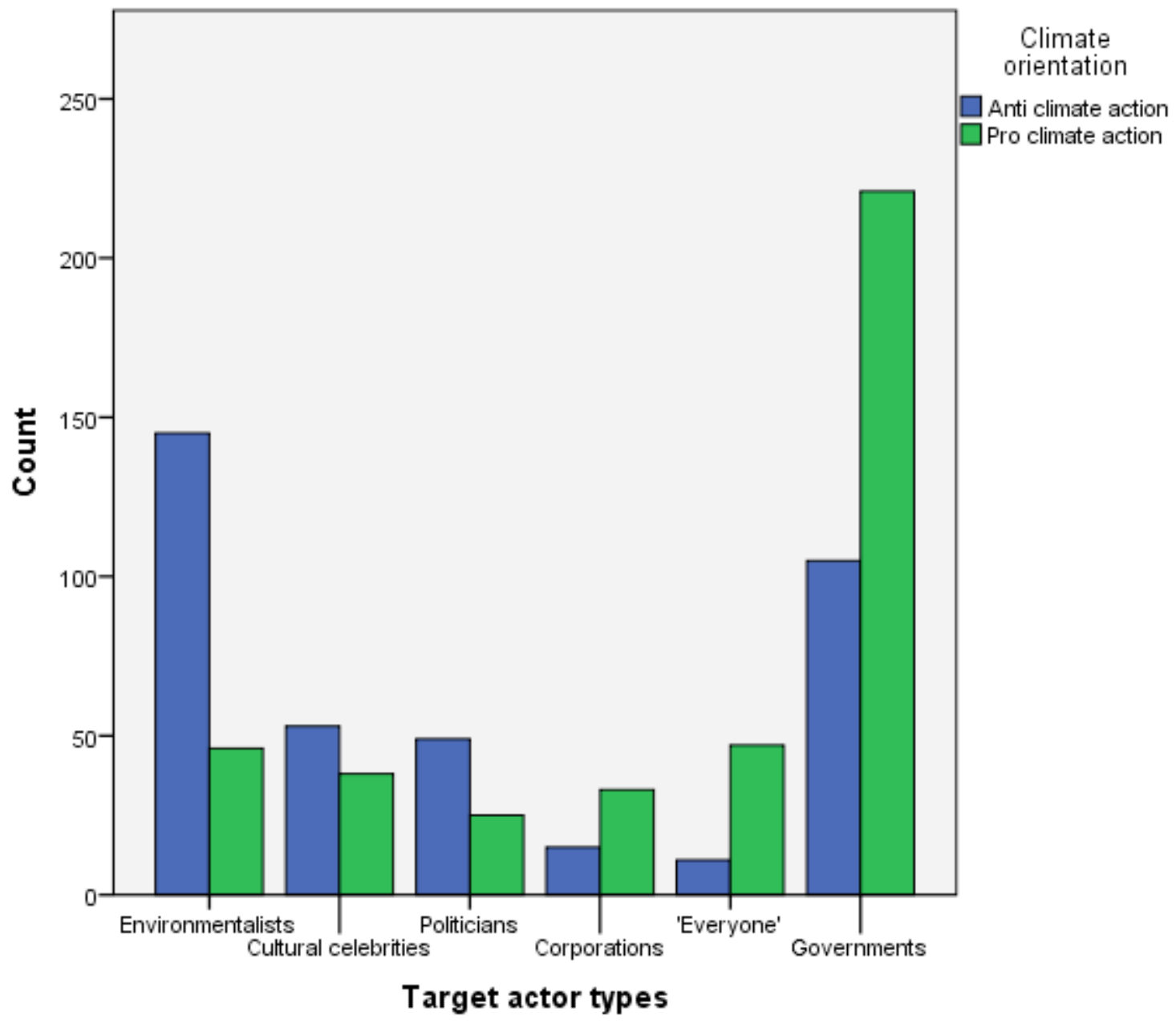


Figure 7. Top 10 individual target actors by climate orientation.

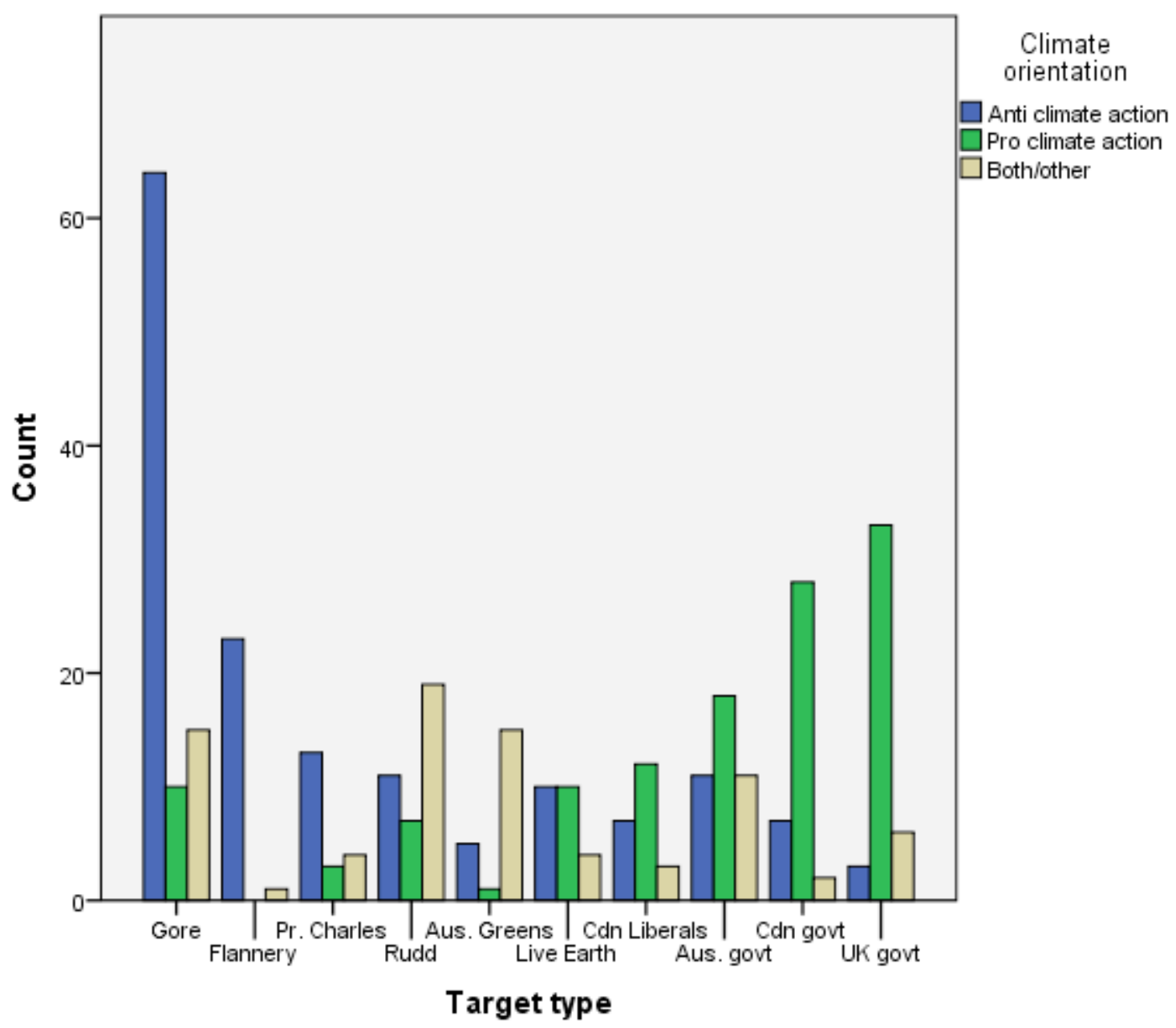


Figure 8: Intensity of negative affect by climate orientation.

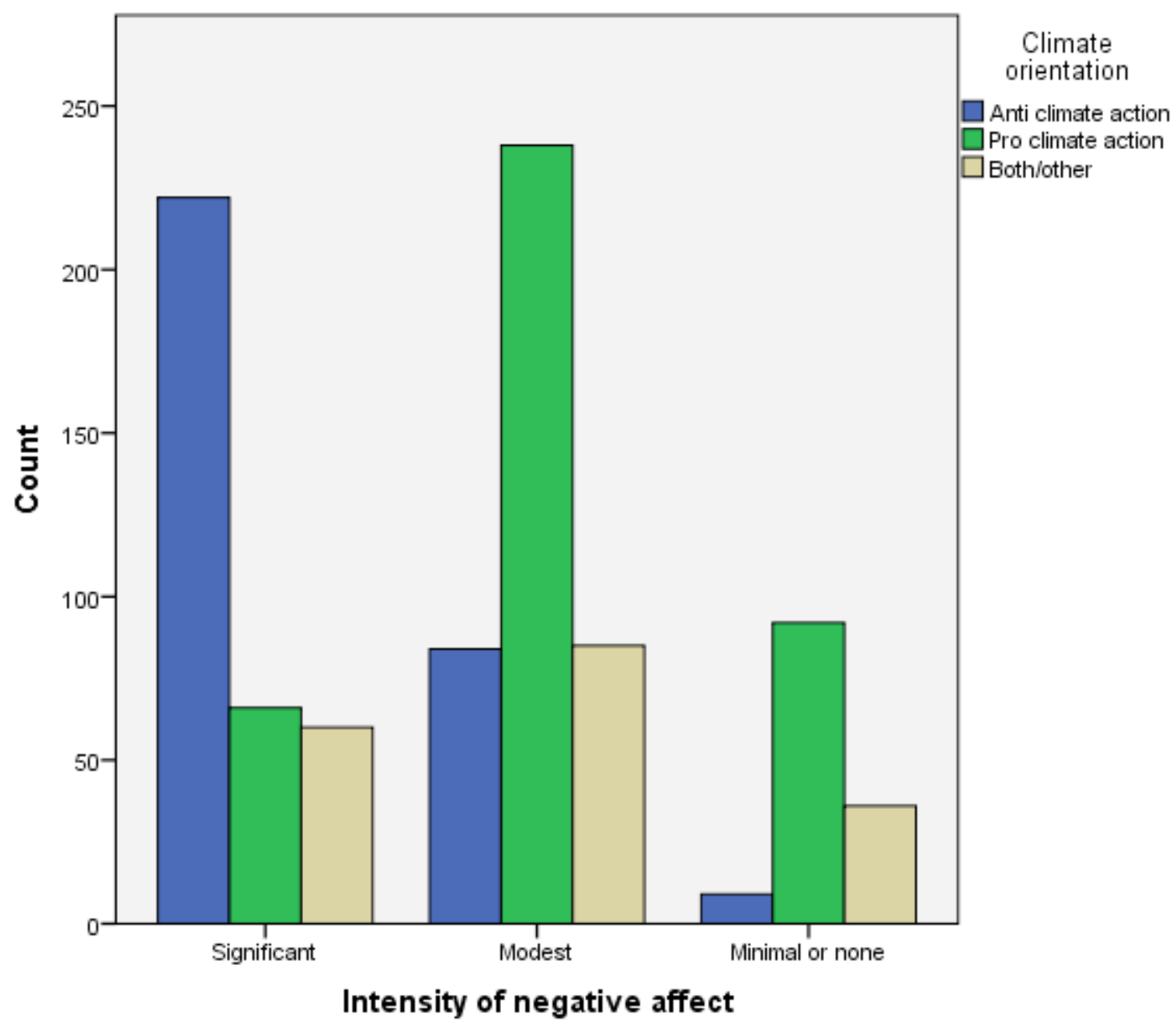


Figure 9. Personal and reflexive hypocrisy by paper.

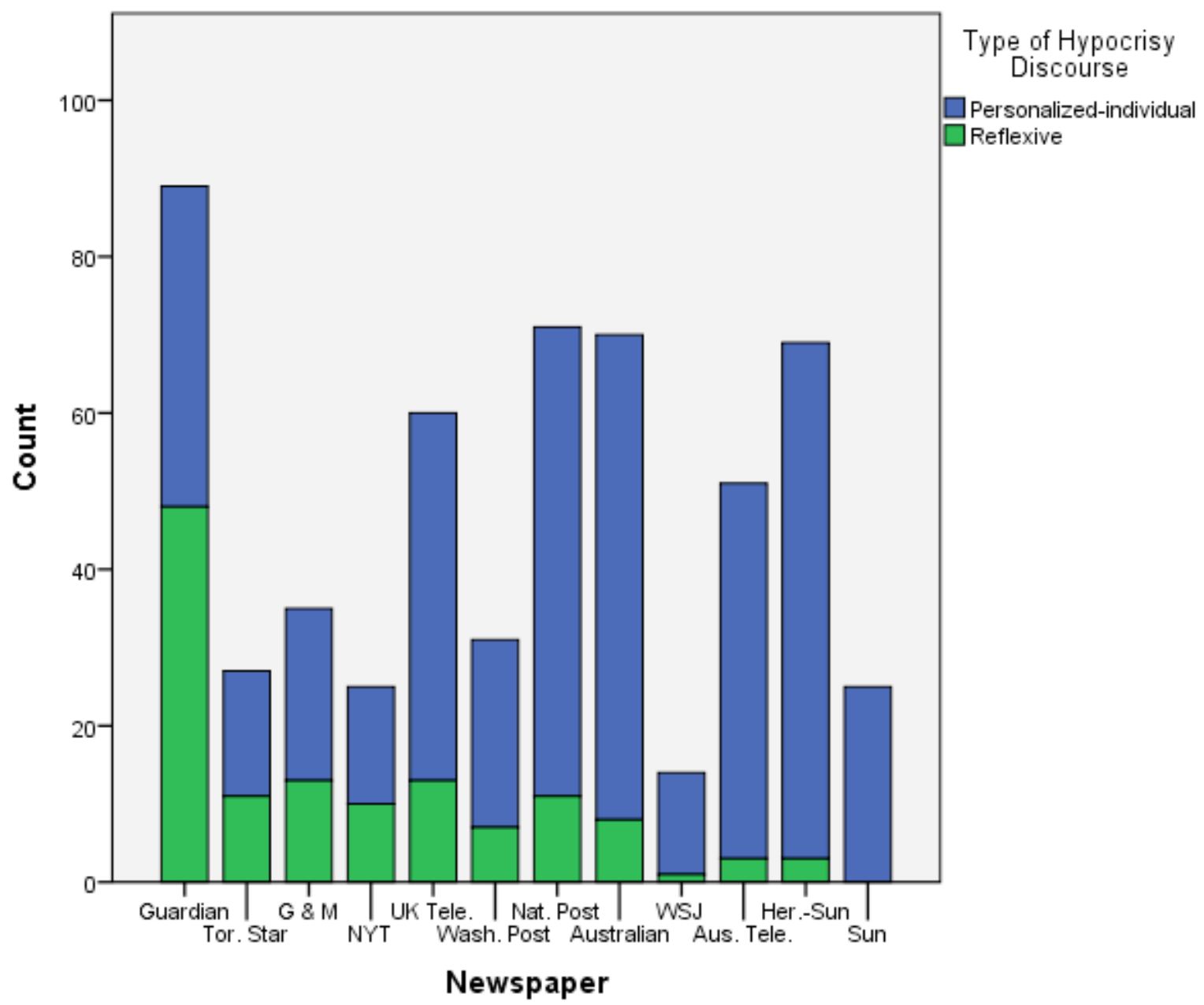


Appendix I: Krippendorff's Alpha coefficients for all variables

\begin{tabular}{|l|l|}
\hline Variable & Krippendorff's alpha \\
\hline Type of climate hypocrisy & \\
- Personalized hypocrisy & .855 \\
- Institutional/analytic hypocrisy & .853 \\
- Reflexive hypocrisy & .792 \\
\hline Climate change orientation & .849 \\
\hline Climate science denial & .819 \\
\hline Negative affective intensity & .770 \\
\hline Type of target & .843 \\
\hline Particular target actor & \\
- Environmentalists - yes/no & .848 \\
- Politicians (as individuals) - yes/no & .852 \\
- Cultural celebrities - yes/no & .887 \\
- Governments and/or political parties - yes/no & .952 \\
- Corporations - yes/no & .927 \\
- Everyone & .876 \\
\hline Type of target behaviour & \\
- Consumer and/or lifestyle - yes/no & .831 \\
- Institutional and/or structural - yes/no & .899 \\
\hline Target lifestyle behaviour & \\
- General emissions and/or energy usage - yes/no & .887 \\
- Flying - yes/no & .909 \\
- Driving - yes/no & .812 \\
- Diet - yes/no & .883 \\
- Household consumption - yes/no & .845 \\
- Luxury consumption - yes/no & .859 \\
\hline Target event & \\
- International climate summit/s) - yes/no & .903 \\
- LiveEarth concert - yes/no & 1.00 \\
- Earth Day - yes/no & 1.00 \\
\hline
\end{tabular}

